\title{
Determinants of initial training for engineering educators
}

\section{Dr. Elizabeth Pluskwik, Minnesota State University, Mankato}

Elizabeth leads the Engineering Management and Statistics competencies at Iron Range Engineering, an ABET-accredited project-based engineering education program of Minnesota State University, Mankato. She enjoys helping student engineers develop entrepreneurial mindsets through project-based and experiential learning. Her research interests include improving engineering education through faculty development, game-based learning, and reflection. Elizabeth was a Certified Public Accountant and Controller in a manufacturing company; her Ph.D. in Organization and Management is from Capella University, Minneapolis. Elizabeth and her husband have a photography business in northern Minnesota.

\section{Dr. Mani Mina, Iowa State University of Science and Technology}

Mani Mina is with the department of Industrial Design and Electrical and Computer Engineering at Iowa State University. He has been working on better understanding of students' learning and aspects of technological and engineering philosophy and literacy. In particular how such literacy and competency are reflected in curricular and student activities. His interests also include Design and Engineering, the human side of engineering, new ways of teaching engineering in particular Electromagnetism and other classes that are mathematically driven. His research and activities also include on avenues to connect Product Design and Engineering Education in a synergetic way.

\section{Dr. John Heywood, Trinity College Dublin}

John Heywood is professorial Fellow Emeritus of Trinity College Dublin- The University of Dublin. he is a Fellow of ASEE and Life Fellow of IEEE. he is an Honorary Fellow of the Institution of Engineers Ireland. He has special interest in education for the professions and the role of professions in society, and the work of ASEE's TELPhE division from whom he has received a best paper and meritorious service awards. He is author of Engineering Education. Research and Development in Curriculum and Instruction which received an outstanding research publication award from the Division for the Professions of the American educational Research Association. He is also author of The Assessment of Learning in Engineering Education: Practice and Policy; The Human Side of Engineering, and Empowering Professional Teaching in Engineering

\section{Prof. Arnold Neville Pears, Royal Institute of Technology (KTH)}

Arnold Pears received his BSc(Hons) in 1986 and PhD in 1994, both from La Trobe University, Melbourne, Australia. He is currently Professor and Chair of the Department of Learning in Engineering Sciences at the KTH Royal Institute of Technology, Sweden. Previous positions as lecturer and senior lecturer at La Trobe University between 1991 and 1998. In 1999 he was appointed senior lecturer at Uppsala University, Sweden. He was awarded the Uppsala University Pedagogy Prize in 2008, and inducted as Professor of Computing Education Research in 2017. He has served on the Uppsala University Academic Senate, as Programme Director for the IT Engineering programme, selection committee for the Uppsala University Pedgogy prize and the educational advisory board of the Faculty of Technology and Natural Sciences.

He has a strong interest in teaching and learning research in computer science and engineering, Professor Pears has published more than 40 journal articles, and is well known as a computing And engineering education researcher through his professional activities in the ACM, and IEEE. Other appointments include Board of Governors of the IEEE Computer Society, steering committee of the Frontiers in Education Conference and as Chair of the Special Technical Community (STC) for Education. He is a Director of CeTUSS (The Swedish National Center for Pedagogical Development of Technology Education in a Societal and Student Oriented Context, www.cetuss.se) and the IEEE Education Society Nordic Chapter. 


\section{Determinants of initial training for engineering educators}

Introduction and background

The beginning of the twenty-first century has seen a spiraling in the costs of university tuition. The UK and the USA are now the most expensive countries in the world in which to educate oneself (see Figure 1).

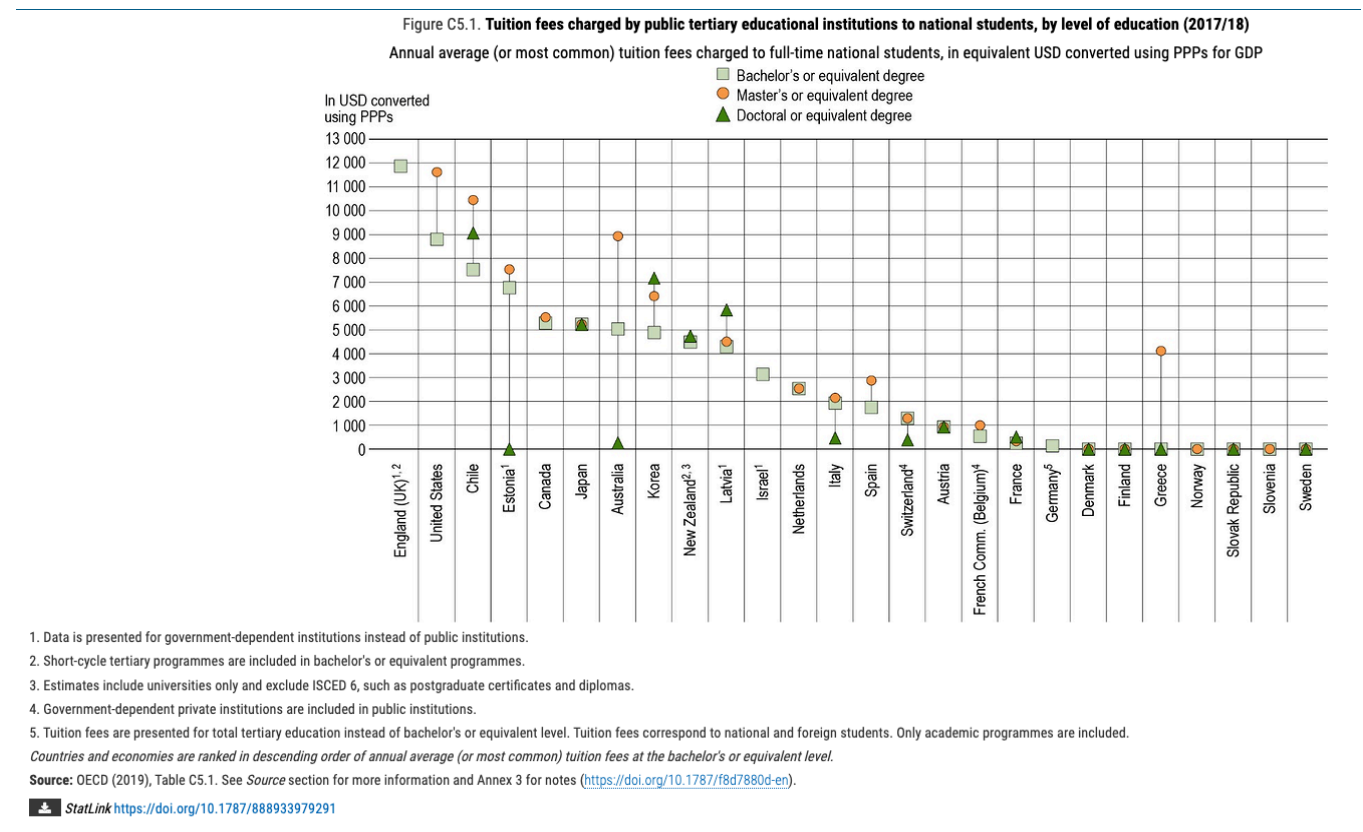

Figure 1: OECD 2017/2018 Fee Data by Country [1]

Recent research shows that in many instances it is a struggle for middle class families to cope with these costs. Caitlin Zaloom shows that families "make college work at any cost", which transforms family life, not necessarily for the better [2]. In the US, this prompts families to consider alternative approaches to higher education, such as community colleges. The pressure from students is nonetheless for university education, rather than vocational education, despite high fees in the hope this leads to better paid employment. In both countries, describing the situation as being at crisis levels is not too strong a phrase.

Questions about the added value of higher education, lead also to questions being asked about the extent to which the teaching offered contributes to that value. Paradoxically there exists a large body of knowledge about how people learn and the conditions for effective learning, why the curriculum persists, how it may be changed, and how a new curriculum may be designed that relates to engineering.

Unlike schoolteachers, the majority of university-level engineering educators in many countries receive little or no training in pedagogy or the philosophies that underpin them before they begin 
teaching, or for that matter during their teaching. With the odd exception, engineering $\mathrm{PhD}$ programs generally do not include courses on teaching and learning, so new faculty generally teach how they were taught, an approach that has primarily focused on transmitting information [3].

Educational training is emerging as a priority area for academics in a number of countries, with formal courses being offered [4]. Evidence of pedagogical education or training is being required for appointment and promotion (especially to the level of full professor).

In Sweden for instance 15 European Credits of higher education pedagogical coursework, including educational innovation in a course setting, is required in order to be eligible for appointment as a lektor (Associate Professor) or Professor in all Swedish Universities. Associate Professors can be appointed without these higher education course credits but are required to take these credits within four to five years to receive tenure.

Systems of career recognition have been established in a significant number of these Universities. Examples include appointment as Excellent Teacher at Uppsala University, and no less than four different models for appointing Excellent Teaching Practitioners at Lund University. Winka in her review of processes for career recognition in teaching at Swedish Universities in 2017 [5] concluded that 22 of 47 Higher Education Institutions had established such systems. Similar requirements are emerging in many European countries [6]. There is also a substantial movement in some UK universities to provide initial teacher training of university professors in a way similar to that provided to K-12 teachers. Increasingly, British universities are requiring that applicants have a teaching qualification recognized by Advance HE (previously the Higher Education Authority). The Staff and Educational Development Association would claim to have had a profound influence on learning and teaching in higher education and the work of Advance HE [7]. In the UK some university departments of engineering now offer parallel career routes in teaching and research [4].

Ireland has a thriving network for engineering education research; Austria has the International Society for Engineering Pedagogy (IGIP) [8] at the University of Klagenfurt, founded in 1972. It offers a substantial qualification in engineering education pedagogy.

Our assertion is that the USA should not risk being left behind, and thus it is imperative that a wider cohort of early career engineering educators should acquire substantial pedagogical and educational training during their initial year(s) of teaching. "Pedagogy" being taken to mean instructional techniques, and "educational" to encompass the curriculum and the philosophies that underpin pedagogies. Four propositions support this view:

1. Assuming that teaching is a professional activity, it is incumbent on a professional to be aware of the knowledge that constructs the activity and act therein taking into account the evidence available.

2. Without such knowledge it is difficult to adapt or lead educational change that is perceived to be beneficial in the classroom or the curriculum or the organization (including the levels of policy, curriculum and instruction). 
3. Given the increasing costs of tuition, it is incumbent on educators and educational organizations to ensure that teaching is of the highest quality and that the curriculum responds to the needs of the learner and society as currently understood.

4. There is a gulf between engineering education research and the practice of engineering that can only be bridged if engineering educators possess a breadth of knowledge that will enable them to read, perhaps try for themselves, and to evaluate educational research findings.

For a number of years, several members of the American Society for Engineering Education (ASEE) thought that ASEE should engage in the recognition of educational qualifications if it was to be a truly professional society. It was felt that ASEE had a professional responsibility to encourage all new engineering educators to gain an initial teaching qualification, not to be confused with subsequent faculty development. There were no courses equivalent to IGIP [9] but there were a few well established and recognized courses that were regularly offered (e.g. NETI) [10]. The opportunity to pursue this issue came when Professor Arnold Pears invited one of us to join him in presenting a one-day workshop on evidence-based teaching for persons with little or no knowledge (experience) of developments in pedagogy in engineering education. Between 2016 - 2019, Arnold offered four similar workshops on evidence-based teaching, the philosophy and curriculum of engineering education, professionalism in engineering education, and related topics. The authors of this paper co-led the series of workshops, as detailed below.

Our purpose in this paper is to present the intentions and experiences of the authors in giving this series of workshops as a model course in initial engineering educator education (Exhibit 1). We share what we have learned, in the tradition of Parlett and Hamilton's concept of illuminative evaluation [11] and John Elliott's model of action research [12 and Endnotes].

Rationale for study

One purpose of this proposed initial training for engineering educators is to provide teachers with the breadth of knowledge required for them to read and act on education research. That is an ideal. It is our experience that that does not happen unless it is followed up by continuing professional development with structured intention. Centers of teaching and learning would be helped if they knew that the experienced educators with whom they have to deal had had substantial initial training in teaching and learning. Felder \& Hadgraft noted in 2013:

"We believe that if engineering education research were stopped completely right now (which we are by no way advocating), and engineering faculties could be induced to put into practice everything we currently know about teaching and learning from past research, cognitive science, and experience, then we would achieve innovation with impact to an extent beyond the wildest dreams of the most idealistic reformers" [13].

From our perspective, the initial course that the authors held multiple times is one that might be used as a starting point in the process of credentialing faculty levels of proficiency in professional education. 
This paper describes our evaluation by action research accomplished by us over three years, five events (four workshops and one reflection event), with various iterations of a workshop, each with a small group of participants. This is our "reflection" on what we did, lessons learned, and our ideas for future similar courses and workshops for initial educator training.

We did not set out to achieve an overall judgment on the five workshop sessions because sample sizes were small. Therefore, we present a reflection supported by prior experience and attention to the literature. Its purpose is to "illuminate" what happened with a view to understanding whether or not our objectives were achieved and to directing the way forward. See Endnotes for further description of "Illuminative evaluation" as described by Parlett and Hamilton [11]. Basically, it is a research model that can be applied in situ; that is, in action research of the kind defined and described John Elliott for his model of school-based accountability [12].

\section{Historical Overview}

This section describes the workshops held and key takeaways from each. Workshops and reflection events were held, as shown in Exhibit 1:

\begin{tabular}{|l|l|l|l|}
\hline Date & Conference & Location & $\begin{array}{l}\text { Number of } \\
\text { workshop } \\
\text { participants }\end{array}$ \\
\hline Oct., 2016 & FIE 2016 & $\begin{array}{l}\text { Lake Erie, } \\
\text { Pennsylvania }\end{array}$ & Ten \\
\hline Oct., 2017 & FIE 2017 & Indianapolis, Indiana & Nine \\
\hline June, 2018 & ASEE 2018 & Salt Lake City, Utah & $\begin{array}{l}\text { Ten reflection } \\
\text { participants }\end{array}$ \\
\hline Oct., 2018 & FIE 2018 & San Jose, California & Five \\
\hline Oct., 2019 & FIE 2019 & Cincinnati, Ohio & Six \\
\hline
\end{tabular}

Exhibit 1: The dates, conferences, locations, and number of participants at each of the workshops hosted by the authors as iterations of a "model" initial course for educational proficiency.

The first workshop - October 12 ${ }^{\text {th }}, 2016$ at the Frontiers in Education Conference (FIE) Lake Erie, Pennsylvania:

When Arnold negotiated this workshop, it was the first time that FIE had approved a full day colocated workshop. The IEEE Computer Society Special Technical Community (STC) for Education sponsored the event and ensured that participants received an IEEE-CS certificate of participation. The workshop was titled "Evidence-Based Teaching, Principles, and Practice" and 
was to be a compressed version of his substantial 10-week course at Uppsala University in Sweden. The published advertisement is shown in Exhibit 2.

The workshop is aimed at those interested in improving their teaching practice from the known literature in engineering education. The target audience ranges from the new instructor to experience faculty interested in advancing the quality of teaching practice. This workshop provides an overview of relevant research literature and provides participants with hands on advice on choice of research approaches, data collection methods, and analysis techniques in the Scholarship of Teaching and Learning in Engineering.

The workshop consists of presentations, group discussions and review of case studies in the engineering education literature. Workshop activities and materials are drawn from faculty development courses in engineering education offered at Uppsala University, Sweden since 2010.

Workshop participants will:

Acquire portfolio of best practices in STEM education.

- Read and discuss selected articles from the STEM higher education research literature

Review models for systematic investigation of learning phenomena.

Reflect on application of STEM education theories to their own teaching.

Result: equipped to conduct evidence-based innovation and evaluation.

Exhibit 2: The workshop advertisement was included in the FIE 2016 Conference information. The one-day workshop was titled "Evidence-Based Teaching, Principles, and Practice" and had ten participants. The workshop was structured as a lecture, followed by discussion.

Ten persons registered for the course including Prof. Mani Mina, who is well known in the field and a friend of the workshop leaders, Arnold and Prof. John Heywood. In the way usual to workshops, the meeting began with the participants exchanging information about who they were and what their goals were for the workshop. This was followed by Arnold who began his lecture with the lament that many students were not satisfied by the educational experiences they had received (some even said they were "frustrated"). With the aid of models, he argued that the educational experience would be improved if teachers understood the body of knowledge that existed in cognitive psychology and assessment strategies. It was an aspect of professionalism that teachers should know and use them and not rely on gut feeling. They should also do research and collect evidence on how people learn, so that a more systematic approach to tracking what they do in courses and in demonstrating what it means to be an engineer, could be used. This raised questions about the need for theories, how and what evidence is collected, and benchmarking.

Mani recorded that most of the afternoon was devoted to discussion, following an information talk from John. The group discussed issues that arose from Arnold's talk. In so doing, they gave more information about themselves, what they taught, what their challenges were, and what they would like further information about. More came out about what they wanted from the workshop. In these circumstances, it is not surprising that the discussion focused on the personal problems of the participant, in particular the teaching versus research conflict. The discourse was governed by the dicta "thou shalt produce papers in an internationally peer reviewed journal". 
Throughout the day, Arnold exhorted the participants to undertake some classroom research activity during the following year to explore ideas obtained during the workshop and said that the workshop leaders would be available on-line for discussion and help. He also hoped there would be a follow-up workshop in 2017.

During the rest of the conference, Mani spoke with all those who attended the workshop. He found that some were a little upset by one participant who constantly aired his views, and wanted to hear other ideas, challenges and questions which could be commented on by the workshop leaders.

Reflection on the first workshop:

Based on the overall activities, as well as the one-to-one discussions, it became clear that in order to benefit from the workshop, the participants need to be encouraged to develop more reflective thinking and reflective practice regarding their teaching and their scholarship as educators. In the post-course deliberations, it became clear that there would have to be a follow-up workshop, and that individuals would have to do some classroom research activity in between workshops.

A pattern for a two-year model emerged:

(1) a two-day workshop at FIE.

(2) Home based work supported by tutorial advice (and perhaps additional online learning).

(3) One- or two-day workshop at the following ASEE annual conference to report on accomplishments.

(4) Further home-based work to be reported at the next FIE. This cycle to be repeated and completed at the following FIE.

This course schedule would require eight days of attendance. The advertised ExCEEd Teaching Workshops [14] require six days attendance but also intervening study and experiential work. We also believed that more could be made of the workshop if the participants had undertaken some prior reading.

John was so struck by the similarity with the problems faced by the beginning schoolteacher (K12) that he felt that the workshop should have begun with a discussion of accountability.

Therefore, in the weeks following, he wrote three essays on accountability in which he discussed the question: "What is a professional?" He answered this with an adaptation of Hoyle's model of restricted and extended professionalism [15] for schoolteachers, extended to higher education [16]. See Appendix A for Hoyle's model.

John argued that teaching was something more than classroom practice - it related to both the ecologies of the classroom, department (school) and institution. Research supports this view and, in particular, the Hamilton College study [17] showed that to improve the student's experience of college, the single most important thing in the quality of student's education was to do with the way the college is organized to help the students with their relationships, and that goes for the classroom experience as well. 
Subsequently he pursued the question of what could be learned from teacher education and used the three essays as an introduction to a more substantive book "Empowering Professional teaching in Engineering: Sustaining the Scholarship of Teaching” [18].

The second workshop - Oct., 2017 at the FIE 2017 Conference in Indianapolis, Indiana:

The second course was held at FIE 2017 in Indianapolis, Indiana. The workshop was advertised in the FIE 2017 program but with no details. John had prepared the "Empowering Professional Teaching in Engineering" [18] book that, though ready to publish, was not available in print in time for the second workshop. However, we did circulate an electronic copy about a fortnight before the workshop. See overview of chapters in Exhibit 3. Nine participants attended, including five from Iron Range Engineering, two others from the US and Canada, and Mani, who acted as a participant observer in this and subsequent workshops. None of the participants from Workshop \#1 returned or engaged in any follow-up discussion during the prior year, so the workshop leaders had to start again with basically the same format as the first workshop. The leaders tried to foster discussion among the attendees.

Arnold presented a summary of the content from the initial faculty courses required at Uppsala University, Sweden. Topics included active learning and its effects on other courses, the goals of universities, assessment, and using constructive alignment theory to effect real change. John was adamant that it's all about the philosophy, and that engineering educators can and should establish themselves as professional educators through relevant teacher training. He also encouraged each educator to conduct informal, active research in their own program, to conduct research-based teaching to see what works in that environment and to analyze it and create new theories. Action research in situ was described as being appropriate for this type of learning about one's own teaching and its effectiveness.

Both Arnold and John again encouraged participants to co-create a community of reflective practice and report back on what they learned about our own practice of teaching, their developing philosophy of education, and being able to defend it through evidence-based action research. What works? When and why and how? They suggested that participants connect theory and practice using an engineering frame of mind; that trying to learn to teach is like a big design problem, with uncertain constraints and variables. The leaders sincerely offered to help the participants over the next year via virtual meetings phone, email, Skype calls, and encouraged goal setting, reflective teaching, and reporting back in eight months at the next ASEE conference.

Reflection on the second workshop:

A group of faculty participants from Iron Range Engineering did carry out action research in the following year, as suggested by the workshop leaders. None contacted the workshop leaders for additional guidance or mentorship, however. 
The Third Event - Iron Range Engineering Report-Out - June 2018 at the ASEE 2018 Conference in Salt Lake City, Utah:

The third event deviated from the established pattern, as it was co-designed and organized with Iron Range Engineering faculty as one-day workshop at ASEE's 2018 Annual Conference. The primary objective was to report on their application of workshop content over the past eight months and interact with Arnold, John and Mani in a scholarly discussion about how to proceed in development of their innovative engineering education programs.

At this workshop the ten participants (individually) reported on what they had adopted from the second workshop content; several had attended the second workshop and the rest were their colleagues; this was the intended audience/participants. From our point of view this was very useful. In addition to the report-outs, workshop leaders compiled an extensive set of materials including publications and examples of student teacher investigations of their own teaching. These were provided to the participants electronically. Mani spoke about reflective practice and self-directed learning and the need for highly adaptive people ready for cognate transfer, that is solve problems they have not seen before by transferring prior knowledge to new situations. This is a very difficult thing for a person to do, and one of the key goals of education is to scaffold the ability to do this. Many theories were discussed, such as Dewey, Kolb, McMurray, Newman, and Whitehead. John's book “The Human Side of Engineering” [19] was discussed.

Arnold presented educational innovation as a goal, training for reflective practice, and practicebased research in the classroom. One participant commented that innovation and change happen at the faculty level, not the administration level.

Participants reported on what they had tried and learned about themselves as educators and their insights in a two-hour discussion. This was highly interactive and valuable. One junior faculty member shared her reflective practice and resulting classroom changes. A senior educator shared the practice of having reflective Faculty Summits twice each year and also about holding students accountable for their own long-term learning to match the programs envisioned outcomes. A highly valued credentialing or certification system within ASEE was also discussed. When asked if this reflective/report-out workshop was a good idea, all of the participants said "yes."

The workshop ended with a call for participants to respond to these reflective questions within two weeks:

- What theories of education interest me?

- How does this influence my teaching?

- What data and insights do I gain?

- How can I reflect this back into teaching?

One participant sent in their reflection. 
Reflection on the third event:

Looking at what we found out in this meeting and comparing it with other meetings that we had, it is clear that different participants need slightly different approaches. The structure of this workshop was guided by the participants with respect to the philosophical as well as practical aspects of being an educator envisioning the role of the faculty in classes and the system. Previous workshops had adopted a predetermined stance in this regard, which is not optimal in terms of empowering responsive and reflective practice. We consider the co-design approach developed in the third event to be a natural progression from the general foundation, the laying of which was the goal of the first and second workshops.

Each member of faculty has his or her way of practice and has found the most effective (and at times efficient) way to conduct classes. When faced with the material that we provide, it takes time for the participants to identify the perspective of the writer and organizers. This is not a simple journey. One needs to not only understand what one does, why one does it, and what one would like to change...in addition the person needs to know the perspective of the workshop, as well as the perspective of the author(s) of the material. These can create mismatch of perspectives and need for communication at different levels.

Our experience shows that the philosophical perspective and the "belief system" of the participant is the most important item that determines the usefulness of the workshop for them. That is assuming that the participants have spent time reading the material and identifying the issues of challenge and ideation. In our experience, this pre-workshop reading rarely happens, but we feel it is essential. A "carrot" is needed to motivate the participants.

We can conclude by observing that what Iron Range Engineering is looking for is not really aligned with what other participants were looking for. That is why we devised the set of reflection questions. But, only one person answered. Why? For one of two reasons. Either they did not have time, or perhaps the questions were not easy for them to answer and were poking into too much personal philosophical disposition that is not easy for many participants to think about.

The fourth workshop - Oct 2018 at the FIE 2018 Conference in San Jose, California:

The workshop was attended by five participants, including four from Iron Range Engineering who had been at the previous workshop. One of them is recognized as an engineering education researcher who has made significant contributions to the literature. The fifth participant was from San Jose University, the city hosting the conference. New participation was dwindling. A similar one-day format was conducted, with the same workshop goals, but with the addition of an discussion of "extended professionalism" from Hoyle.

Arnold, John, and Mani all presented briefly, then discussion with group members ensued. Arnold emphasized that there is a body of knowledge on cognitive psychology and assessment strategies, and that teachers need to know and use these. That is an aspect of professionalism. A discussion of the notion of "professional educator" followed. It was noted that university 
environments are very different from industry, and $\mathrm{PhD}$ programs do not prepare new engineering faculty for effective teaching and learning.

Other topics discussed were active learning, inquiry-based learning, the role of the teacher ("We are the windows into the profession"), oral exams, open-ended questions, classroom research, changing technologies, and more. Participants were encouraged to develop their own theory of instruction and learning over the coming year, to recognize that it will change with experience, and to report and publish their findings. Assessment, data gathering, and reflection were emphasized.

A lengthy discussion on the curriculum followed, including how the whole curriculum is so much more than a series of courses or pedagogical techniques. Onboarding new faculty as well as the tension between expectations of teaching and traditional research was discussed at length. Questions such as "How does one stay current in both education and disciplinary research?" were discussed. Many theories and resources were suggested to aid the participants in ongoing self-study. The huge gulf between current education research and the language of the classroom was noted, as well as the need for multidisciplinary, agile problem-solving skills that industry needs and that this is not often taught in university programs. Trevelyan writes on this extensively in his 2019 paper [20].

The goal of establishing a basic teaching credential was again discussed and its importance was agreed upon. John iterated that there is a body of knowledge about education, and that to be a professional educator, one must master it, as well as the technical area of expertise. Again, all three workshop facilitators verbally offered to engage in ongoing communication with participants through email, Skype or phone calls, and that they welcomed participants to contact them during the coming year.

Reflection on the fourth workshop:

Mani, acting as workshop participant/observer related that this workshop reemphasized what we learned from our last event. Through weekly Skype calls among the authors, we are gradually focusing on how to work with a broad interest and experience of the faculty that we see in these sessions. Also, we are now sure that due to the difficulties of time and travel, most if not all of the participants do not have time to read the material and think about it. A summary of the issues, and items to focus on before joining the first meetings was proposed.

The fifth workshop - Oct 2019 at the FIE 2019 Conference in Cincinnati, Ohio:

Following our principle of a co-designed experience in event three and influenced by perceptions of dwindling interest from a broader public, the fifth event was framed as a workshop on curriculum design and assessment. The focus on curriculum, and policy making related to the curriculum, resulted in a number of new attendees with that specific interest. Relevant prior reading was provided electronically to participants just a few days before the workshop, and they were asked to read them, if time allowed. 
John had attempted a volume-length study of the principles of the curriculum in which most of the points were illustrated by an actual case study. Again, we had an agreement for it to be published by Morgan and Claypool, but we had been unable to get it out on time. An electronic script was available to the workshop participants.

Due to the percentage of new participants, Arnold decided to give the same introduction as for the first workshop. This meant that Assessment was not specifically addressed.

John attended this event as an observer via Skype, and Arnold and Mani led the discussion with five new participants. No previous workshop participants returned, apart from Elizabeth, who was co-designer and facilitator. This group introduced themselves and their goals for the day; similar problems and challenges with balancing teaching and research were reported, as well as a lengthy discussion on what "engineering" actually is. The group saw engineering as a series of courses, merely content delivered via various pedagogies, the holistic view of curriculum was largely absent, the theories of teaching and learning, and action research were discussed. There was a lively discussion on what makes an excellent teacher and how the institutions recognize it (or don't). Arnold gave an overview of various educational models, such as virtual campus, using mobile devices, using video meetings for synchronous collaborative work, MOOCS, learning in context, and more. We presented them with a model for the curriculum process (see Exhibit 4). Elizabeth provided some examples of active learning and action research in her program.

Similar to previous workshops, this was primarily an introduction to the models and philosophies of teaching and learning. New to this session was a pre-workshop survey which asked the participants about their goals for the workshop. A few were completed and returned, so this gave some focus to the discussion, but without the prior reading having been done, little new progress was made. One participant inquired if there would be another offering the following year, as he would like to bring his colleagues.

Reflection on the fifth workshop:

Our view is that the participants' notion of curriculum as a series of content divided into subjects and delivered via pedagogical techniques has limited their thinking. We presented them with a model for the curriculum process (see Exhibit 4), but found it challenging to alter their frameworks at the one-day workshop. There are different understandings of learning, which lead to different curricula. Relevant prior reading was provided electronically to participants just a few days before the workshop, and few had time to read the articles. If the participants had done the prior reading and examined their own understanding first, we would have been on a common starting basis.

Significantly, one participant did address the heavy challenges placed on university professors with comments like "We must reduce the grading load on faculty" and "Many teachers are better researchers than teachers." Mani spoke about the need for learners to be brave and to reflect and to share one's thoughts, as well as the transition from college to industry. The Hamilton College work is relevant [17] suggesting that the environment and relationships in the learning time and space are so very critical to learning. 
An unfortunate but notable fact is that the workshop leaders had consistently invited participants

to conduct their own action research studies and report back the following year, but very few had done so.

\section{Discussion:}

(a) General findings

A notable weakness of the workshops was the lack of guided prior reading and activity-based follow-ups. It is clear that this cannot be achieved without a carrot which predisposes participants to invest time in pre-workshop learning. This state of affairs is due in part to the fact that the pre-reading materials were sent to the workshop participants a short time in advance; they should have been sent much earlier. We conclude that a couple of weeks is not enough time for participants to thoughtfully complete the pre-work, though it is not clear that more time would have helped, given busy academic schedules and shortages of time for day to day work. Mani acted as a participant observer and interviewed all the participants and found that no one reads the pre-reading material at all. It is also evident that the content is not contextually available to the participants on the first reading. Even if they do read it, the application and contextualization is difficult until after much discussion at the workshop and subsequently an opportunity to implement action research in the classroom.

Similarly, the curriculum workshop did not achieve its goals due to a lack of prior knowledge of educational philosophy from which to derive the aims and objectives of the curriculum. The workshops overall came nowhere near providing the prior knowledge framework that an extended professional engineering educator might be expected to possess. This has profound implications for the design of future courses for beginning teachers of engineering and allied subjects.

(b) Findings related to becoming a professional engineering educator

One of us (John) was much affected by the fact that much of the discussion seemed to focus on the personal problems of the teacher, in particular the teaching versus research conflict. It seemed there were no lines of accountability and that everything was governed by a strong motivation to write papers to be published in internationally peer reviewed journals. He also noted a similarity with the problems faced by the beginning schoolteacher and considered that the workshop should have begun with a discussion of accountability.

(c) Recommendations for the profession

We maintain that teaching is something more than classroom practice - it relates to both the ecologies of the classroom, department (school) and institution. Research supports the view that the way the college is organized to help the students with their relationships with their peers, 
teachers, and staff is the single most important factor in the quality of student's education [17]. Ironically the relationships that teachers have with their students is not mentioned in the characteristics of an extended professional by Hoyle. Nonetheless the social capital and supportive relationship between learner and teacher is very important for the quality of learning. As a sum, the professional is responsible for the work they do to a variety of stakeholders. This means that a professional must take responsibility for their own teaching and to be acceptable in the current climate of academic discourse it must be evidence-based. There are, it seems, two meanings of "evidence-based" functioning in this context. The first relates to independent evidence for and against a range of techniques in the literature that can lead to changes in teaching technique. The second relates to the evaluation of the technique when practiced by one's self and whether it works for "you" ("me") which may or may not validate the published research. These two meanings have also been related to the concept of "teaching as research". Eisner's idea of educational connoisseurship [21] and the idea of doing research on one's own teaching [18] are both relevant. This idea has also been taken up (independently) in the US by Angelo and Cross [22], and Cross and Steadman [23]. The former concerning Classroom Assessment Techniques (CATS), and the latter, classroom research. We are strongly influenced here by the position of Patricia Cross, who claimed that teaching in higher education would not acquire status until teachers treated their classrooms as laboratories for research. The "new" discipline of engineering education research, the question of who should be doing it, and how it can be accomplished with rigor has been discussed at FIE and ASEE since 2000 [24]. Taken together, these essays argue that there is such a thing as a "scholarship of teaching". Although, from an engineering perspective, teaching may also be regarded as design.

Reflections on the workshop series:

Once a teacher begins to explore the scholarship of teaching, so they are necessarily drawn into philosophy (epistemology when it relates to technique: ontology when it relates to the person and organization).

Our series of workshops are an attempt at an initial course of study for engineering educators. The goal was to help participants to begin to examine their own philosophy of teaching and learning as a start towards action research and an evaluation of what works for them and their students in the context of their learning environment. Our findings from the analysis of the five events organized so far follow:

A key feature of the conduct of workshops is to strengthen feelings of belonging and a community with shared values. Participants always want to get to know each other, of course, but for many it seems that this is a rare opportunity to meet and exchange ideas with like-minded colleagues. Once they are invited to talk, no matter what question you ask, they will respond and turn it towards their own specific concerns. The tension between teaching and research was a challenging problem that our workshop participants repeatedly raised.

We were unable to develop the program into a series (educational sequence) because we had virtually no repeat participants; we envisaged a workshop series which would continue with a group of interested faculty through online discussions and report-outs at the following FIE or ASEE conferences. Motivation for continued involvement clearly requires additional 
mechanisms; we find in the US college situation that this seems to especially concern institutional recognition and value.

In the spirit of action research as defined by John Elliott, we were seeking refined hypotheses. For example, we (or at least one of us) believed not only that the engineering curriculum needed to change, but that such a change could not be brought about without the participants understanding their own philosophies, that is the collectives of their values and beliefs, and examining these in the light of different theories of knowledge. While this was not tested, the attitudes of participants revealed deep-seated beliefs about the curriculum that were the cause of the problem they wished to examine. In the short workshop time available, we were not able to dislodge these beliefs.

Recommendations for staff developers and workshop organizers

Based on our reflective analysis of the workshops conducted to date we make the following recommendations as initial determinants:

1. The participants should be required to pre-read the materials and to complete pre-workshop activities to explore their own problems. Also, workshop leaders should communicate the entire course content to the participants in advance of the workshop, allowing for modifications. If we had, the participants could have framed their problems in light of the planned discussion. The facilitators must be able to adapt to what is happening in the course and pivot based on expressed participants needs.

2. Facilitators need to encourage the participants to recognize that they have needs; then frame these needs in respect to their challenges in curriculum and instruction.

3. We suggest careful planning of a combination of workshop and distance learning activities and to build in time for participants to explore their own problems, individually, then in small groups. One 5 or 6-hour workshop session is not enough to cover the wide breadth of content. Similarly, a continuing professional relationship with others is also needed to join research, development, and publication in a meaningful way. Planned distance learning activities both before and after the workshop act in concert to develop a community of learners.

4. Future facilitators should listen to participants' top two challenges, then document and address them. We experienced that there was a conflict between the participants' expectations and ours. The content of the workshop or follow-up activities may need to change as a result; it is important to have agreed-upon expectations for the course outcomes.

5. There is a need for those in engineering education to be aware of what is happening in education generally, as well as industrial training, where literature is developed and available. Engineering education has tended to close itself off from relevant sources of high-quality education research, such as in medical education.

6. The development of professional educators requires a "carrot." We recommend facilitating motivation in the form of a recognized qualification that is valued by faculty members, other 
instructors, deans, higher education administration, and promotion and tenure committees. Efforts to develop extended professionalism and use of high-quality theories of education will not be successful without valued rewards for educators. That's why we could not get people to return to our workshops. Recognition, compensation, and/or advancement in ones' career need to be connected to efforts to develop extended professionalism, starting with initial training.

\section{A final word:}

Upon reflection, we realize that the workshop participants had not developed an appreciation for extended professionalism (see Appendix A). Their common understanding is that because they have deep knowledge via an engineering PhD degree, they assume they are "qualified" and are "professional." They don't operate under the criteria of extended professionalism, and this is what is hindering them.

Our course, exemplified by this series of workshops, served to test a series of hypotheses about initial teacher training to bridge the gap between current education research findings and contextual action research and classroom application. This is our professional responsibility and together, in a community of support, we can provide motivation and excitement around the scholarship of teaching and learning, to benefit our students, our universities, and ourselves. 


\section{Exhibit 3}

\begin{tabular}{|c|c|}
\hline $\begin{array}{l}\text { Empowering Professional } \\
\text { Teaching in Engineering (seen } \\
\text { as journey for which reason the } \\
\text { chapters are called journeys). } \\
\text { Journey titles }\end{array}$ & Journey sections \\
\hline $\begin{array}{l}\text { 1. Accountable to whom? Learning from } \\
\text { beginning schoolteachers } 1 \text {. }\end{array}$ & $\begin{array}{l}\text { Introduction/Accountability in higher education/accountability and } \\
\text { evaluation in schools/accountability and professionalism }\end{array}$ \\
\hline $\begin{array}{l}\text { 2. Oh that we had the gift of God to see } \\
\text { ourselves as others see us. Learning } \\
\text { from beginning teachers } 2 \text {. }\end{array}$ & $\begin{array}{l}\text { Introduction/recording one's class/perceptual learning in the classroom/Elliot } \\
\text { Eisner's concept of educational connoisseurship. }\end{array}$ \\
\hline $\begin{array}{l}\text { 3. Toward a scholarship of teaching. } \\
\text { Teaching as research }\end{array}$ & $\begin{array}{l}\text { Introduction/the scholarship of teaching/teaching as design/ teaching as } \\
\text { research. An approach to scholarship. }\end{array}$ \\
\hline 4.Objectives and outcomes & $\begin{array}{l}\text { Social efficiency ideology/the objectives movement/The Taxonomy of } \\
\text { educational Objectives/Eisner's objections to the objectives } \\
\text { approach/instructional planning/questioning, questions and classroom } \\
\text { management/reconciliation: a conclusion }\end{array}$ \\
\hline $\begin{array}{l}\text { 5. Problem solving: its teaching and } \\
\text { curriculum process }\end{array}$ & $\begin{array}{l}\text { Introduction/definitions and approaches to teaching problem solving/types of } \\
\text { problem: difficulty and complexity/assessment, instruction and objectives - } \\
\text { the curriculum process/difficulty in, and time for learning }\end{array}$ \\
\hline $\begin{array}{l}\text { 6. Critical thinking, decision making } \\
\text { and problem solving }\end{array}$ & $\begin{array}{l}\text { Introduction/teaching a decision-making heuristic/qualitative } \\
\text { strategies/critical thinking/ a category for problem solving? }\end{array}$ \\
\hline $\begin{array}{l}\text { 7. The scholar academic ideology of the } \\
\text { disciplines }\end{array}$ & $\begin{array}{l}\text { Introduction/the received curriculum or the scholar academic ideology/the } \\
\text { post-Sputnik reform projects/discovery (inquiry) based learning/ is } \\
\text { engineering a discipline? }\end{array}$ \\
\hline 8. Intellectual development & $\begin{array}{l}\text { The spiral curriculum/engineering and the school curriculum/Curriculum } \\
\text { questions raised by Piaget's theory of cognitive development/Intellectual } \\
\text { development: Perry and King and Kitchener }\end{array}$ \\
\hline 9. Organization for learning & $\begin{array}{l}\text { Introduction/the advanced organizer/using advanced organizers/prior } \\
\text { knowledge. Memory/cognitive organization/mediating responses/impact of } \\
\text { K-12 and career pathways. }\end{array}$ \\
\hline 10. Concept learning & Robert Gagné/Misperceptions/using examples. \\
\hline 11. Complex concepts & $\begin{array}{l}\text { Complex and fuzzy concepts/staged development/concept mapping and key } \\
\text { concepts. }\end{array}$ \\
\hline $\begin{array}{l}\text { 12. The learning centered ideology. How } \\
\text { much should we know about our } \\
\text { students? }\end{array}$ & $\begin{array}{l}\text { Introduction/Communities of practice, communities of care/learning } \\
\text { styles/convergent and divergent thinking/Kolb's theory of experiential } \\
\text { learning/Felder and Solomon's index of learning styles/temperament and } \\
\text { learning styles. }\end{array}$ \\
\hline 13. Intelligence & IQ and its impact/psychometric testing/controversies. \\
\hline
\end{tabular}




\begin{tabular}{|l|l|} 
14. two views of competency & Nature vs Nurture. Nature and nurture/inside and outside competencies \\
\hline 15. From IQ to emotional IQ & $\begin{array}{l}\text { Introduction/ implicit theories of intelligence. Formal and unintended but } \\
\text { supportive/emotional intelligence/practical intelligence. }\end{array}$ \\
\hline 16. Social reconstruction & $\begin{array}{l}\text { The fourth ideology/constructive controversy/debate/mock trials/turning the } \\
\text { world upside down/a case study for conclusion. }\end{array}$ \\
\hline
\end{tabular}

Exhibit 3 - framework by John Heywood in his book "Empowering Professional teaching in Engineering: Sustaining the Scholarship of Teaching " [18]

\section{Exhibit 4}

\begin{tabular}{|c|c|}
\hline $\begin{array}{l}\text { "Designing Engineering and } \\
\text { Technology Curricula: } \\
\text { Embedding Educational } \\
\text { Philosophy" by John Heywood }\end{array}$ & Chapter sections \\
\hline 1. The language we speak & $\begin{array}{l}\text { The meaning of words and phrase/The Vienna Circle/Ambiguity in } \\
\text { engineering education/ Defining literacy and technological literacy/The } \\
\text { language of engineering/An alternative scenario: the theatrical/To } \\
\text { summarize/Notes and references }\end{array}$ \\
\hline 2. The curriculum & $\begin{array}{l}\text { Terminology in education/ From terminology through identity to an } \\
\text { operational philosophy/ Defining the curriculum: the curriculum as } \\
\text { process/The curriculum process and the overloaded curriculum/The } \\
\text { curriculum as a mix of ideologies/The aims of education Notes and } \\
\text { references }\end{array}$ \\
\hline 3. In search of aims & $\begin{array}{l}\text { Introduction/Tuition fees in the United States/What is higher education } \\
\text { for?/Tuition fees in the UK. The Graduate premium/An alternative structure } \\
\text { for UK degree programs/ The quality of teaching/Grade inflation and the } \\
\text { usefulness of some degree programs/ Questions about the purposes of } \\
\text { higher education/ Conclusions/ Notes and references }\end{array}$ \\
\hline $\begin{array}{l}\text { 4. Technology and the changing structure } \\
\text { of the workforce }\end{array}$ & $\begin{array}{l}\text { Impact of technological workforce forecasting on educational } \\
\text { policy/Specific shortages/Changing patterns in employment prospects in } \\
\text { engineering. Toward an alternative model of higher education/The impact } \\
\text { of technology on professional work/The new "middle skill" jobs/Hybrid } \\
\text { jobs/Technology portends a new type of degree/Conclusions/Notes and } \\
\text { references }\end{array}$ \\
\hline 5. Education in service of employment & $\begin{array}{l}\text { Graduates for industry/Shaping the environment and Sternberg's theory of } \\
\text { intelligence/Responses by policy makers to industrial complaints about } \\
\text { higher education/The development of professional competencies: } \\
\text { reconciling two philosophies/ Conclusion/Notes and references }\end{array}$ \\
\hline $\begin{array}{l}\text { 6. Adaptability, transfer of learning and } \\
\text { liberal education }\end{array}$ & $\begin{array}{l}\text { Adaptability and the transfer of learning/The responsibility of } \\
\text { employer/Enlargement of mind and adaptability/ Expertise and liberal } \\
\text { education/ Community and learning/Conclusion/Notes and references }\end{array}$ \\
\hline
\end{tabular}




\begin{tabular}{|l|l|} 
7. Society and technology & $\begin{array}{l}\text { The aims of higher education/Prospects, determining the program/ } \\
\text { Examples of "bridging" key concepts/The "over-arching" concept of } \\
\text { design/ Whitehead's rhythmic theory of learning/The goals of a stage of } \\
\text { "romance" in a program for engineering and technological literacy/The } \\
\text { stage of romance and content/Conclusion/Notes and references }\end{array}$ \\
\hline
\end{tabular}

Exhibit 4 - A model for the curriculum process, an overview John Heywood's unpublished book "Designing Engineering and Technology Curricula: Embedding Educational Philosophy"

\section{End Note:}

Action research originated in school-based curriculum reform in secondary modern schools in the UK that began in the late 1960's. It is a form of teaching-as-research. In the US in 1986 Patricia Cross argued that if higher education was to be reformed college teachers should begin to treat their classrooms as laboratories. John Elliott writes "it is process which is initiated by practicing teachers in response to a particular practical situation which they (teachers) confront". In the circumstances of curriculum reform "the practical situation is one in which their traditional curriculum practices have been destabilized and rendered problematic by the development of students resistance or 'refusal' to learn' ". In higher education substantial curriculum change is extremely difficult because of the press of the educational culture. Elliott continues "The innovations proposed arouse controversy within the staff group (faculty) because they challenge the fundamental beliefs embodied in existing practices about the nature of learning, teaching and evaluation." In the process "issues are clarified and resolved in free open collegial discourse, characterized by mutual respect and tolerance for others' views, in the absence of power constraints on the discussion's outcomes".

In Elliot's school-based model "change proposals are treated as provisional hypotheses to be tested in practice within the context of collegial accountability to the whole staff group" while the management facilitates a 'bottom up' rather than a 'top-down' approach to the development of curriculum policies and strategies". Many faculty would argue that that is what we do when we change the curriculum. We were not, however, seeking to change the curriculum, but to develop a model curriculum by testing it out in a workshop situation by obtaining the responses (or lack of response) from those engaged in the activity and some observers who appeared and went from time to time.

In 1972 Parlett and Hamilton published an essay on illuminative evaluation. In it they challenged the agricultural-botany model of evaluation in favor of what they called an" illuminative" model. It aims to evaluate an innovative program, how it operates, how it is influenced by the situation, its merits, demerits as seen by the participants, and how student intellectual tasks and experiences are affected. It is a research model that can be applied in situ that is, in action research of the kind defined and described John Elliott for his model of school-based accountability. 


\section{Appendix A:}

Eric Hoyle's model of restricted versus extended professionality [15], the model used by Heywood in his book "Empowering Professional teaching in Engineering: Sustaining the Scholarship of Teaching" [18].

\begin{tabular}{|l|l|}
\hline Restricted professionality & Extended professionality \\
\hline Skills derived from experience & $\begin{array}{l}\text { Skills derived from mediation between experience and } \\
\text { theory }\end{array}$ \\
\hline Perspective limited to immediate time and place & Perspective embracing broader social context of education \\
\hline $\begin{array}{l}\text { Class (lecture) room events perceived in } \\
\text { isolation. }\end{array}$ & $\begin{array}{l}\text { Classroom events perceived in relation to institution policies } \\
\text { and goals }\end{array}$ \\
\hline Introspective with regard to methods & $\begin{array}{l}\text { Methods compared with those of colleagues and with reports } \\
\text { of practice. }\end{array}$ \\
\hline Value placed on autonomy. & Value placed on professional collaboration. \\
\hline $\begin{array}{l}\text { Limited involvement in non-teaching professional } \\
\text { activities }\end{array}$ & High involvement in non-teaching professional activities. \\
\hline Infrequent reading of professional literature. & Regular reading of professional literature. \\
\hline $\begin{array}{l}\text { Involvement in CPD limited and confined to } \\
\text { practical courses. }\end{array}$ & $\begin{array}{l}\text { Involvement in CPD work considerable including courses of } \\
\text { a theoretical nature. }\end{array}$ \\
\hline Teaching seen as an intuitive activity. & Teaching seen as a rational activity. \\
\hline
\end{tabular}




\section{References:}

[1] OECD, Education at a Glance 2019: OECD Indicators. Paris: OECD Publishing, 2019. [Online]. Available: https://doi.org/10.1787/f8d7880d-en. [Accessed 02-Apr-2020].

[2] C. Zaloom. Indebted. How Families Make College Work at Any Cost. Princeton, NJ. Princeton University Press, 2019.

[3] K. Trigwell and M. Prosser (2004). "Development and Use of the Approaches to Teaching Inventory," Educational Psychology Review, 16(4), pp. 409-424. [Online]. Available: https://doi.org/10.1007/s10648-004-0007-9. [Accessed 02-Apr-2020].

[4] K. Fraser, R. Greenfield, \& G. Pancini (2017). "Conceptualising institutional support for early, mid, and later career teachers," International Journal for Academic Development, vol 22, no. 2, pp.157-169. [Online]. Available: https://doi.org/10.1080/1360144X.2016.1218882. [Accessed 02-Apr-2020].

[5] K. Winka, "Mapping the landscape of tertiary education meritocracy systems for university pedagogy in Sweden's higher education system”, Gothenburg, Department of Educational Development and Interactive Learning (PIL), University of Gothenburg, Sweden, 2017. [Online]. Available: http://urn.kb.se/resolve?urn=urn:nbn:se:umu:diva-138097. [Accessed 02-Apr-2020].

[6] R. Graham, "The Career Framework for University Teaching: background and overview," London: Royal Academy of Engineering, 2017. [Online]. Available: https://www.raeng.org.uk/publications/reports/career-framework-for-university-teachingbackground. [Accessed: 02-Apr-2020].

[7] Staff and Educational Development Program. [Online]. Available: https://www.seda.ac.uk/ [Accessed: 30-Jan-2020].

[8] IEE Certification Program. [Online]. Available: http://igip.education/information/ [Accessed: 30-Jan-2020].

[9] IGIP Training Centers. [Online]. Available: http://www.igip.org/IGIP training-centres.php. [Accessed: 02-Apr-2020].

[10] National Effective Teaching Institute of ASEE. [Online]. Available: https://www.asee.org/education-careers/continuing-education/courses-and-workshops/neti [Accessed: 30-Jan-2020].

[11] M. Parlett and D. Hamilton, Evaluation as illumination. A New Approach to the Study of Innovatory Programmes. Edinburgh: Centre for Research in Education Sciences, 1972.

[12] J. Elliott, Action Research for Educational Change. Buckingham: Open University Press, 1991. 
[13] R. Felder and R. Hadgraft, "Educational Practice and Educational Research in Engineering: Partners, Antagonists, or Ships Passing in the Night?," Journal of Engineering Education, vol. 102, no 3, pp 339-345, July, 2013.

[14] American Society of Civil Engineers. "ExCEEd Teaching Workshop," [Online]. Available: https://www.asce.org/exceed/ [Accessed: 30-Jan-2020].

[15] E. Hoyle. Professional Development of Teachers: World Year Book of Education, Professionalization and deprofessionalization in E. Hoyle and J. Megarry (Eds). London: Kogan, 1980.

[16] J. Heywood and A. Cheville, "Is engineering education a professional activity?" in Proceedings of the American Society for Engineering Education, ASEE2015, Seattle, WA, USA, June 14-17, 2015. [Online]. Available: https://peer.asee.org/24382 [Accessed: 30-Jan2020].

[17] D. F. Chanbleiss and C. G. Takacs, How a College Works. Cambridge, MA: Harvard University Press, 2014.

[18] J. Heywood, Empowering Professional teaching in Engineering: Sustaining the Scholarship of Teaching, San Rafael, CA: Morgan and Claypool, 2018. [E-book] Available: DOI: $\underline{10.2200 / S 00830 E D 1 V 01 Y 201802 E N G 029}$

[19] J. Heywood, The Human Side of Engineering. San Rafael, CA: Morgan and Claypool, 2017. [E-book] Available: DOI: 10.2200/S00748ED1V01Y201612ENG028

[20] J. Trevelyan, "Transitioning to engineering practice," European Journal of Engineering Education, vol 44, no 6, pp 821-837, 2009. [Online] Available: DOI: $10.1080 / 03043797.2019 .1681631$

[21] E. Eisner, The Enlightened Eye: Qualitative Inquiry and the Enhancement of Educational Practice. New York, NY: Teachers College Press, 2017.

[22] T. Angelo and P. Cross, Classroom Assessment Techniques: A Handbook for College Teachers (2nd Ed.), San Francisco, CA: Jossey-Bass, 1993.

[23] P. Cross and M. Steadman, Classroom Research: Implementing the scholarship of teaching. San Francisco, CA: Jossey-Bass, 1996.

[24] J. Heywood, personal communication, Apr 2, 2020. 